\title{
Hardness and fracture toughness of resin-composite materials with and without fibers
}

DOI:

10.1016/j.dental.2019.05.017

\section{Document Version}

Accepted author manuscript

Link to publication record in Manchester Research Explorer

\section{Citation for published version (APA):}

Alshabib, A., Silikas, N., \& Watts, D. C. (2019). Hardness and fracture toughness of resin-composite materials with and without fibers. Dental Materials. https://doi.org/10.1016/j.dental.2019.05.017

\section{Published in:}

Dental Materials

\section{Citing this paper}

Please note that where the full-text provided on Manchester Research Explorer is the Author Accepted Manuscript or Proof version this may differ from the final Published version. If citing, it is advised that you check and use the publisher's definitive version.

\section{General rights}

Copyright and moral rights for the publications made accessible in the Research Explorer are retained by the authors and/or other copyright owners and it is a condition of accessing publications that users recognise and abide by the legal requirements associated with these rights.

\section{Takedown policy}

If you believe that this document breaches copyright please refer to the University of Manchester's Takedown Procedures [http://man.ac.uk/04Y6Bo] or contact uml.scholarlycommunications@manchester.ac.uk providing relevant details, so we can investigate your claim.

\section{OPEN ACCESS}




\title{
Hardness and fracture toughness of resin-composites with and without fibers.
}

Short Title: Composites with and without fibers.

\author{
Abdulrahman Alshabiba, \\ Nick Silikas ${ }^{\mathrm{a}}$ \\ David C Watts ${ }^{\mathrm{a}}$ \\ ${ }^{a}$ School of Medical Sciences, Division of Dentistry, University of \\ Manchester, UK \\ ${ }^{b}$ Department of Restorative Dentistry, College of Dentistry, King Saud \\ University, Riyadh, Saudi Arabia.
}

Corresponding authors:

Prof. Nikolaos Silikas

University of Manchester, School of Medical Sciences

Coupland 3 Building, Oxford Road, Manchester M13 9PL, UK

Email: nick.silikas@manchester.ac.uk

\section{Prof. David C Watts}

University of Manchester, School of Medical Sciences and Photon Science Institute

Coupland 3 Building, Oxford Road, Manchester M13 9PL, UK

Email: david.watts@manchester.ac.uk 


\begin{abstract}
Objectives: To investigate the surface micro-hardness (VHN) and fracture toughness $\left(\mathrm{K}_{\mathrm{IC}}\right)$ of resin-composites, with and without incorporated short fibers, after solvent storage.
\end{abstract}

Methods: Three resin-composites incorporating fibers, additional to particle reinforcement, were examined: everX ${ }^{\mathrm{TM}}$, NovoPro Fill ${ }^{\mathrm{TM}}$ and NovoPro Flow ${ }^{\mathrm{TM}}$. Four composites were used as controls, with only particle reinforcement: Filtek bulk Fill ${ }^{\mathrm{TM}}$, Filtek bulk one ${ }^{\mathrm{TM}}$, Filtek $\mathrm{XTE}^{\mathrm{TM}}$, and Filtek Flow XTE ${ }^{\mathrm{TM}}$. For hardness measurement, materials were cured in $2 \mathrm{~mm}$ thick molds for $20 \mathrm{~s}$ by a LED source of average irradiance $1.2 \mathrm{~W} / \mathrm{cm}^{2}$. Specimens ( $\mathrm{n}=6 /$ group) were stored dry for $1 \mathrm{~h}$ and then in either water or $75 \%$ ethanol/water for $1 \mathrm{~h}, 1 \mathrm{~d}$ and $30 \mathrm{~d}$ at $37 \pm 1^{\circ} \mathrm{C}$. Vickers hardness was measured under a load of $300 \mathrm{~g}$ for $15 \mathrm{~s}$. For fracture toughness $\left(\mathrm{K}_{\mathrm{IC}}\right)$ measurements, single-edge-notched specimens ( $\mathrm{n}=6 /$ group) were prepared: (32 x $6 \times 3 \mathrm{~mm}$ ) for 3-point bending and stored for 1 and $7 \mathrm{~d}$ in water at $37^{\circ} \mathrm{C}$. Fractured surfaces of fiber-reinforced composite were examined by scanning electron microscopy (SEM). VHN data were analyzed using three-way ANOVA, one-way ANOVA and the Tukey post hoc test $(\mathrm{p} \leq 0.05)$. $\mathrm{K}_{\mathrm{IC}}$ data were analyzed by two-way ANOVA and oneway ANOVA and the Tukey post hoc test $(\mathrm{p} \leq 0.05)$. An independent $\mathrm{t}$-test was used to detect differences $(\alpha=0.05)$ in $\mathrm{K}_{\mathrm{IC}}$ between stored groups for each material.

Results: VHN decreased for all composites with storage time in both solvents, but more appreciably in $75 \%$ ethanol/water (an average of $20 \%$ ). $\mathrm{K}_{\mathrm{IC}}$ ranged from 2.14 (everX Posterior) to 0.96 NovoPro Flow) MPa.m ${ }^{0.5}$.The longer storage period (7 d) had no significant effect on this property relative to $1 \mathrm{~d}$ storage.

Significance: Reinforcement with short fibers, and possibly matrix compositional differences, significantly enhanced the fracture toughness of EVX. However, for nano-fiber containing composites, there were no evident beneficial effects upon either their fracture toughness or hardness compared to a range of control composites. Water storage for 7 days of all these resin-composites produced no significant change in their $\mathrm{K}_{\mathrm{IC}}$ values, relative to $1 \mathrm{~d}$ storage.

Key words: Resin composites, fiber reinforcement, water storage, ethanol/water, fracture toughness, surface hardness. 


\section{Introduction}

Improved physical properties of resin-composites, along with their positive aesthetics, mean that they are now the most frequently used direct materials for restoring both posterior and anterior teeth. Following the Minamata convention, the agreed phase down of amalgam is expected to increase the use of resin-composites in posterior restorations (1). Furthermore, resin-composites are able to strengthen the tooth structure rather than weakening it when compared to dental amalgam (2). While there have been advances in dental composites in recent times, there still remain numerous challenges to achieve the optimal composite formulation. Resin-composites should withstand harsh environments, that differ between patients, as regards occlusal habits, masticatory forces, abrasive foods, temperature changes, bacteria, and salivary enzymes. The lifespan of resin-composite restoration depends highly on these factors (3-5). It is not only the intraoral environment that impacts the longevity; the nature of the resin-composite network itself also has an effect. The crosslink density, porosity, and hydrophilicity of the network, along with the matrix/filler quality and nature of the filler system are all substantial factors $(6,7)$.

Intra-oral degradation is one of the major causes of failure in direct restorations. It may affect a variety of resin-composite properties, including wear resistance, microhardness, dimensional stability, colour stability, and fracture resistance (8-10). Water sorption, temperature, and length of exposure to aqueous media all may have an impact on properties of resin-composites (10). They can be further degraded by certain chemicals introduced into the oral environment by food and drink and from the by-products of acidogenic bacteria beneath the restoration margins (11).

Acceleration of degradation processes has been demonstrated in studies where materials are aged by immersion in solvents that simulate the oral environment (12). This suggests that solvent sorption and resulting degradation may decrease the longevity and performance of resin-composite restorations (13). Simulation of resin-composite degradation in the oral environment may be attempted through the use of food-simulating solvents. These may deteriorate the mechanical properties of a restoration and affect its longevity $(4,10,14)$. If a solvent and a substance share a similar polarity, they will have a tendency towards mutually solubility or at least softening $(15,16)$. For this reason, solvents with solubility parameters between 1.5 and $4.8 \times 10.4\left(\mathrm{~J} / \mathrm{m}^{3}\right)$ may be used for the oral environmental simulation on dental composites $(15,17)$. 
A promising type of resin-composite include fibers as reinforcement. They are aesthetic materials that incorporate glass fibers and can be used in several dental clinical applications, but predominantly in restorative dentistry (18). They can offer enhanced mechanical properties that can be very close to those of the natural tissues (19). The current study aimed to assess how two solvents affected surface hardness, and how water influenced the fracture toughness, of seven resin-composites with and without incorporated short fibers.

The null hypotheses were as follows:

- No difference would be observed in VHN between materials;

- No difference would be observed in VHN values after storage in solvents.

- No difference would be observed in $\mathrm{K}_{\mathrm{IC}}$ between materials;

- No difference in $\mathrm{K}_{\mathrm{IC}}$ between materials at 1 and $7 \mathrm{~d}$ of water storage at $37^{\circ} \mathrm{C}$.

\section{Materials and methods}

The resin-composite materials investigated are presented in Table 1. These are two main groups: i) fiber containing composites and ii) Composites reinforced exclusively with particulate fillers. Both groups were chosen to represent composites used for different clinical applications with varying percentages of resin and filler.

\subsection{Fiber length measurement}

Inorganic components were extracted from NovaPro Universal composite. $0.5 \mathrm{~g}$ of composite paste was placed in a glass container and $20 \mathrm{ml}$ of tetrahydrofuran (THF 99.9\% purity, Lot: 12643750, Fisher Scientific) was added, A spatula was used to stir the THF into the composite paste for two min. The resulting mixture was then separated equally into two tubes before being centrifuged at 4500 -rpm (Heraeus, UK) for $20 \mathrm{~min}$ at $23^{\circ} \mathrm{C}$. The supernatant (separated THF), was extracted using a Pasteur-pipette. The inorganic component was transferred to plastic tubes before being put into an EZ-2 Elite solvent evaporator (Genevac Ltd., SP Scientific Company, UK) for $3 \mathrm{~h}$ to dry at $60{ }^{\circ} \mathrm{C}$. For SEM analysis, a specimen was vacuum sputter coated for two min with $60 / 40 \mathrm{Au} / \mathrm{Pd}$ alloy to form a $10 \mathrm{~nm}$ layer thickness (Q150T ES, Quorum technologies, UK). A SEM (Quanta 650 FEG, FEI company, USA) was used to obtain the images of the nano hydroxyapatite fibers. The images were processed to establish the final fiber lengths, using Image-J software (20). A total of 50 fibers were included in the calculation. 
Table 1: Composition of Materials investigated according to manufacturer's information.

\begin{tabular}{|c|c|c|c|c|c|c|c|c|}
\hline \multicolumn{2}{|c|}{ Material } & \multirow[t]{2}{*}{ Manufacturer } & \multirow{2}{*}{$\begin{array}{l}\text { Lot } \\
\text { number }\end{array}$} & \multirow{2}{*}{$\begin{array}{l}\text { Type and } \\
\text { shade }\end{array}$} & \multicolumn{2}{|c|}{ Filler load } & \multirow{2}{*}{$\begin{array}{l}\text { Filler } \\
\text { type }\end{array}$} & \multirow{2}{*}{$\begin{array}{l}\text { Resin } \\
\text { matrix }\end{array}$} \\
\hline Code & Name & & & & Vol\% & $\mathrm{Wt} \%$ & & \\
\hline NPU & $\begin{array}{l}\text { NovaPro } \\
\text { Universal }\end{array}$ & $\begin{array}{l}\text { Nanova Inc, } \\
\text { Missouri, USA }\end{array}$ & 30001 & $\begin{array}{l}\text { Nano-fibre } \\
\text { reinforced, } \\
\text { nano-hybrid } \\
\text { Conventional } \\
\text { A2 shade }\end{array}$ & --- & 77 & $\begin{array}{l}\text { Barium } \\
\text { Borosilicate } \\
\text { Glass, } \\
\text { Hydrophobic } \\
\text { Amorphous } \\
\text { Silica, } \\
\text { Hydroxyapatite } \\
\text { fibers. }\end{array}$ & $\begin{array}{l}\text { Bis-EMA, } \\
\text { TEGDMA, } \\
\text { UDMA }\end{array}$ \\
\hline NPF & $\begin{array}{l}\text { NovaPro } \\
\text { Flow }\end{array}$ & $\begin{array}{l}\text { Nanova Inc, } \\
\text { Missouri, USA }\end{array}$ & 2001 & $\begin{array}{l}\text { Nano-fibre } \\
\text { reinforced, } \\
\text { nano-hybrid } \\
\text { Flowable } \\
\text { A2 shade }\end{array}$ & ---- & 60 & $\begin{array}{l}\text { Barium } \\
\text { Borosilicate } \\
\text { Glass, } \\
\text { Hydrophobic } \\
\text { Amorphous } \\
\text { Silica, } \\
\text { Hydroxyapatite } \\
\text { fibers. }\end{array}$ & $\begin{array}{l}\text { Bis-EMA, } \\
\text { TEGDMA, } \\
\text { UDMA }\end{array}$ \\
\hline EVX & $\begin{array}{l}\text { ever X } \\
\text { Posterior }\end{array}$ & $\begin{array}{l}\text { GC Corporation, } \\
\text { Tokyo, Japan }\end{array}$ & 1701101 & $\begin{array}{l}\text { Fibre } \\
\text { reinforced } \\
\text { BulkFill } \\
\text { Universal } \\
\text { shade }\end{array}$ & 53.6 & 74.2 & $\begin{array}{l}\text { E-Glass short } \\
\text { fibers,Barium } \\
\text { Borosilicate } \\
\text { Glass } \\
\text { particulate }\end{array}$ & $\begin{array}{l}\text { Bis-GMA, } \\
\text { TEGDMA, } \\
\text { PMMA }\end{array}$ \\
\hline XTE & $\begin{array}{l}\text { Filtek } \\
\text { Supreme } \\
\text { XTE }\end{array}$ & $\begin{array}{l}\text { 3M ESPE, St.Paul } \\
\text { USA }\end{array}$ & N836906 & $\begin{array}{l}\text { Nano-hybrid } \\
\text { Conventional } \\
\text { A2 shade }\end{array}$ & 63.3 & 78.5 & $\begin{array}{l}\text { Zirconia filler } \\
\text { Silica fillers/ } \\
\text { Zirconia and } \\
\text { silica clusters. }\end{array}$ & $\begin{array}{l}\text { Bis-GMA, } \\
\text { Bis-EMA, } \\
\text { UDMA, } \\
\text { PEGDMA }\end{array}$ \\
\hline XTF & $\begin{array}{l}\text { Filtek } \\
\text { Supreme } \\
\text { XTE } \\
\text { Flowable }\end{array}$ & $\begin{array}{l}\text { 3M ESPE, St.Paul } \\
\text { USA }\end{array}$ & N522058 & $\begin{array}{l}\text { Nano-hybrid } \\
\text { Flowable } \\
\text { A2 shade }\end{array}$ & 46 & 65 & $\begin{array}{l}\text { Zirconia filler } \\
\text { Silica fillers/ } \\
\text { Zirconia and } \\
\text { silica clusters }\end{array}$ & $\begin{array}{l}\text { Bis-GMA, } \\
\text { BisEMA,TE } \\
\text { GDMA }\end{array}$ \\
\hline FBF & $\begin{array}{l}\text { Filtek Bulk } \\
\text { fill }\end{array}$ & $\begin{array}{l}\text { 3M ESPE, St.Paul } \\
\text { USA }\end{array}$ & N838840 & $\begin{array}{l}\text { Nano-hybrid } \\
\text { Bulk fill } \\
\text { A2 shade }\end{array}$ & 58.4 & 76.5 & $\begin{array}{l}\text { ytterbium } \\
\text { tytterbium } \\
\text { trioride and } \\
\text { zircon silica }\end{array}$ & $\begin{array}{l}\text { DDDMA, } \\
\text { UDMA, } \\
\text { AUDMA }\end{array}$ \\
\hline FBO & $\begin{array}{l}\text { Filtek One } \\
\text { Bulk fill }\end{array}$ & $\begin{array}{l}\text { 3M ESPE, St.Paul } \\
\text { USA }\end{array}$ & N859232 & $\begin{array}{l}\text { Nano-hybrid } \\
\text { Bulk fill } \\
\text { A2 shade }\end{array}$ & 58.4 & 76.5 & $\begin{array}{l}\text { ytterbium } \\
\text { tytterbium } \\
\text { trioride and } \\
\text { zircon silica }\end{array}$ & $\begin{array}{l}\text { DDDMA, } \\
\text { UDMA, } \\
\text { AUDMA }\end{array}$ \\
\hline
\end{tabular}

Bis-GMA: bisphenol-A-diglycidyl dimethacrylate; Bis-EMA: bisphenol-A-polyethylene-glycol-diether dimethacrylate; TEGDMA: triethylene glycol dimethacrylate; PMMA: polymethyl methacrylate; UDMA: urethane dimethacrylate, DDDMA (1, 12-Dodecanediol dimethacrylate), AUDM: Aromatic urethane dimethacrylate. 


\subsection{Surface Hardness}

Twelve disc-shaped specimens in Teflon molds $(8 \times 2 \mathrm{~mm})$ were prepared according to the instructions provided by their manufacturers for each of the seven resin-composites (Table 1). Each Teflon mold was placed over a clear Mylar strip with glass slides (1 mm in thickness) on each side and then squeezed together. A LED curing unit with measured average tip irradiance of $1200 \mathrm{~mW} / \mathrm{cm}^{2}$ (Elipar S10, 3M Espe, Seefeld, Germany) was applied directly to the specimen for $20 \mathrm{~s}$. Irradiance was verified through the use of a calibrated radiometer every time the light curing unit was used (MARC ${ }^{\text {TM }}$ Resin Calibrator, Blue-light Analytics Inc, Halifax, NS, Canada). Each specimen was subsequently taken from its mold and finished gently on both sides once preparation was complete. For each group a new batch of polishing discs (coarse, medium, fine); were used to remove any excess at the sides of the specimens (OptiDisc; Kerr Hawe SA, Bioggio, Switzerland) using a hand piece (15,000 rpm). Specimens of each material were assigned to one of two groups $(n=6)$ of solvents: distilled water, or $75 \%$ ethanol/water.

The specimens were measured $1 \mathrm{~h}$ after irradiation using a Vickers Micro-hardness Instrument (FM-700, Kawasaki, Kanagawa, Japan), and then again after being solvent stored in the dark at $37 \pm 1^{\circ} \mathrm{C}$ for one and $30 \mathrm{~d}$. Vickers hardness (VHN) was determined using a load of $300 \mathrm{~g}$ at $23 \pm 1^{\circ} \mathrm{C}$ for $15 \mathrm{~s}$. At each time interval three indentations were made on each specimen equal distances apart, and $1 \mathrm{~mm}$ adjacent indentations and specimen margins (Figure 1).

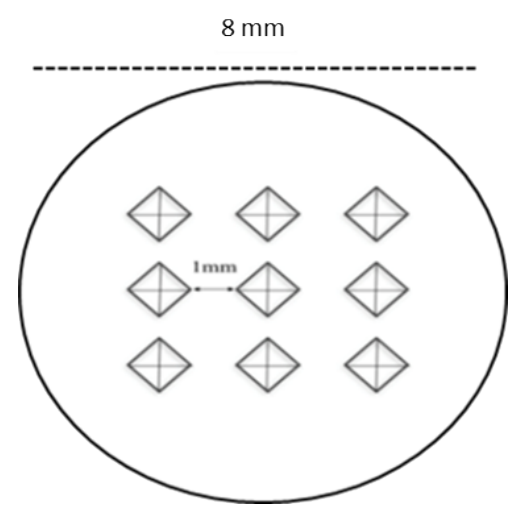

Figure 1: (A): The ca.1 mm distance between Vickers indentations with 9 indentations per specimen

\subsection{Fracture Toughness}

For each of the materials, a polytetrafluoroethylene (PTFE)-lined brass mold was used to produce 12 single edge notched (SEN) specimens. The mold conformed to British Standard 
54479:1978 (21). The specimens were photo-polymerised for a total of $120 \mathrm{~s}$, by a LED curing unit (as mentioned above). Six overlapping areas of irradiation were utilized along the length of the specimens. Small volumes of composite excess at the edges of the specimen were removed using 320-grit metallographic papers before being stored in small bottles of distilled water and placed in an incubator for $24 \mathrm{~h}$ at $37^{\circ} \mathrm{C}$. Using a stereomicroscope (EMZ5; Meiji Techno Co. Ltd. Japan), at $1.5 \times$ magnification, the crack length was measured for each specimen to an accuracy of $0.1 \mathrm{~mm}$. The specimen dimensions were measured using an electronic digital caliper (Powerfix, OWIM GmbH \& Co., KG, Germany) with an accuracy of $0.01 \mathrm{~mm}$. The width and height were measured at the center of the sample and at two different points. The fracture toughness $\left(\mathrm{K}_{\mathrm{IC}}\right)$, were measured by flexural loading with a Universal Testing Machine (Zwick/Roell-2020, 2.5kN load cell) at $23 \pm 1^{\circ} \mathrm{C}$. Each beam specimen was subjected to a central load, in a three-point bending mode, at a crosshead speed of $1.0 \mathrm{~mm} / \mathrm{s}$, until each specimen's fracture point was reached (Figure 2).

From the load values at fracture, fracture toughness was calculated through the following formula (22):

$$
\boldsymbol{K}_{I C}=\left[\frac{P L}{B W^{1.5}}\right] Y
$$

\begin{tabular}{l|c}
$\mathrm{P}=$ Load at fracture & $\mathrm{B}=$ thickness of the specimen \\
$\mathrm{L}=$ distance between the supports & $\mathrm{Y}=$ calibration function for given geometry \\
$\mathrm{W}=$ width of the specimen & $\mathrm{a}=$ notch length \\
$\mathrm{Y}=\left[2.9(a / w)^{1 / 2}-4.6(a / w)^{3 / 2}+21.8(a / w)^{5 / 2}-37.6(a / w)^{7 / 2}+38.7(a / w)^{9 / 2}\right]$
\end{tabular}

Equation 1: Fracture toughness equation 


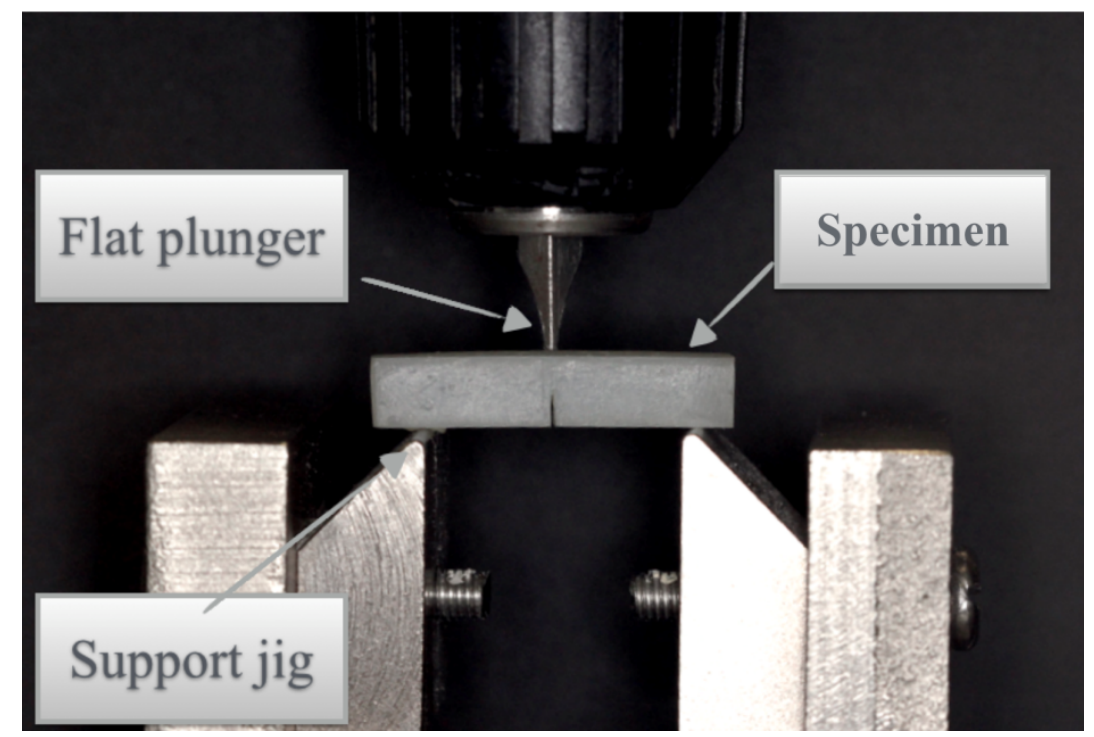

Figure 2: Specimen on the measurement jig of the Zwick UTM instrument (Plunger head measurements $7 \mathrm{~mm}$ length and $1.2 \mathrm{~mm}$ in width).

\subsection{Scanning electron microscopy (SEM) of fractured specimens}

Specimens were vacuum sputter coated for $2 \mathrm{~min}$ with 60/40 Au/Pd alloy to produce a $10 \mathrm{~nm}$ layer thickness (Q150T ES, Quorum technologies, UK). Then the fracture microstructure was observed for the fiber reinforced composites (EVX and NPU) using a Quanta 650 FEG-SEM (FEI company, USA).

\section{Statistical Analysis}

\subsection{Micro-hardness}

Data for all groups were collected and analyzed statistically using SPSS 22.0 (IBM SPSS Statistics, SPSS Inc., New York, USA). Three-way ANOVA, one-way ANOVA, and Tukey post hoc test $(\alpha=0.05)$ was performed to identify the interaction between the materials, solvent, and time (independent) and the hardness (dependent). Levene's test of homogeneity was used to analyse all data for equal variances, following the assumption of equal variance.

To investigate the relationships between hardness and filler loading Quadratic regression analysis was performed. 


\subsection{Fracture toughness}

Data for all groups were collected and analysed statistically using SPSS 22.0 (IBM SPSS Statistics, SPSS Inc., New York, USA). Two-way ANOVA, one-way AVOVA and Tukey post-hoc tests $(\alpha=0.05)$ was performed to identify differences in $\mathrm{K}_{\mathrm{IC}}$ (dependent variable) between different materials and time (independent variables). An independent t-test was utilized for each material and time point (1d vs $7 d$ ).

\section{Results}

\subsection{Fiber length measurements}

The measured length of the nano hydroxyapatite fibers in NovaPro Universal composite varied between $8 \mu \mathrm{m}$ and $103 \mu \mathrm{m}$ (average $41 \mu \mathrm{m}$ ). 64\% of them ranged between $8-50 \mu \mathrm{m}$ (with average length in this group being $24.3 \mu \mathrm{m}$ ), whereas $36 \%$ were between $50-103 \mu \mathrm{m}$ (with average of $71.6 \mu \mathrm{m}$ ). Results are presented in Table 2.

Table 2: Measured fiber lengths

\begin{tabular}{|c|c|c|}
\hline \multirow{2}{*}{} & \multicolumn{2}{|c|}{ Fibre length } \\
\cline { 2 - 3 } & $\mathbf{8}-\mathbf{5 0} \boldsymbol{\mu m}$ & $\mathbf{5 0 - 1 0 3} \boldsymbol{\mu m}$ \\
\hline $\begin{array}{c}\text { Fibre lengths grouped by } \\
\text { average length (mm). }\end{array}$ & 24.3 & 71.6 \\
\hline $\begin{array}{c}\text { Fibre lengths grouped by } \\
\text { percentage values (\%). }\end{array}$ & $64 \%$ & $36 \%$ \\
\hline
\end{tabular}

\subsection{Micro-hardness}

VHN data are presented for each of the composites in Table 1; Figure 3 and Figure 4 gives a graphical representation. At baseline (1 h dry storage), VHN ranged between 33.9 and 67.8, reducing to between 24.7 and 52.7 after ethanol/ water ageing. The highest VHN, both prior to and after storage, was seen in XTE, followed by NPU, and finally NPF, which had the lowest VHN. In specimens stored in 75\% ethanol/water, VHN was significantly influenced by the ageing period (decrease in VHN), where baseline readings (1h) were considerably higher than VHN measured over subsequent time periods $(\mathrm{p}<0.05)$. VHN reduction ranged 
between $12.6 \%$ for NPU, to $28.8 \%$ for EVX. Conversely, specimens stored in water exhibited increased surface hardness after $24 \mathrm{~h}$ storage, with the exception of EVX for which no changes were observed. Nevertheless, following $30 \mathrm{~d}$ storage these values were significantly lower compared to $1 \mathrm{~d}$ measurements $(\mathrm{p}<0.05)$, with the exception of NPU for which no significant changes were observed.

There was a positive quadratic relationships between micro-hardness and, filler loading, (Error! Reference source not found.), with $\mathrm{r}^{2}=0.97$ for baseline data ( $1 \mathrm{~h}$ dry storage), $r^{2}=0.95$ for water storage and $r^{2}=0.95$ for ethanol/water storage. 
Table 3: Vickers hardness VHN (standard deviation) of resin-composites after $1 \mathrm{~h}$ dry, and $1 \mathrm{~d}, 30 \mathrm{~d}$ storage in two solvents at $37^{\circ} \mathrm{C}$

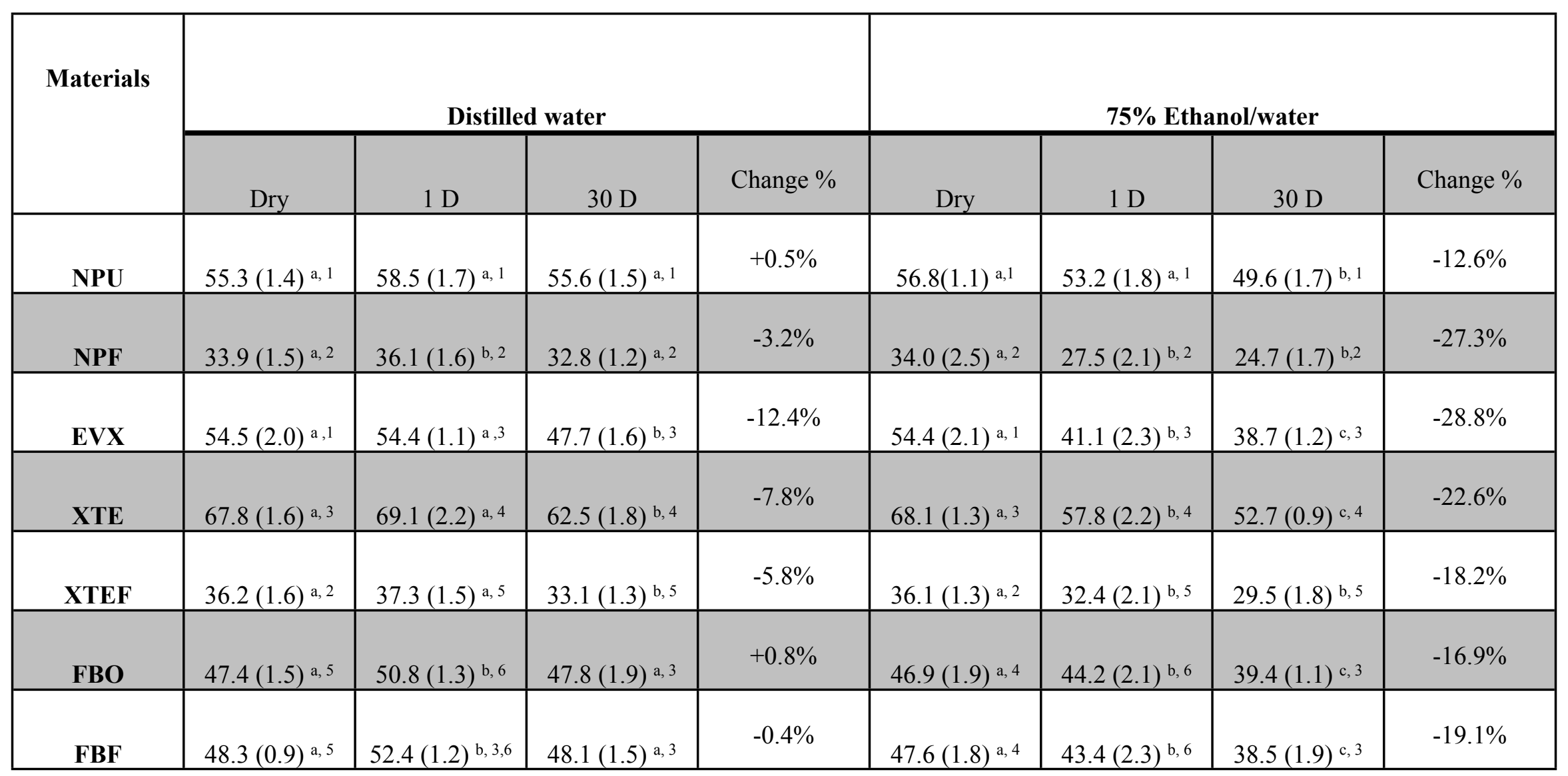

For each solvent the same superscript letters indicates no significant difference $(p>0.05)$.

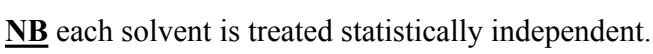

At each time interval same number superscripts indicates no significant difference $(p>$ 


\section{A: Water}

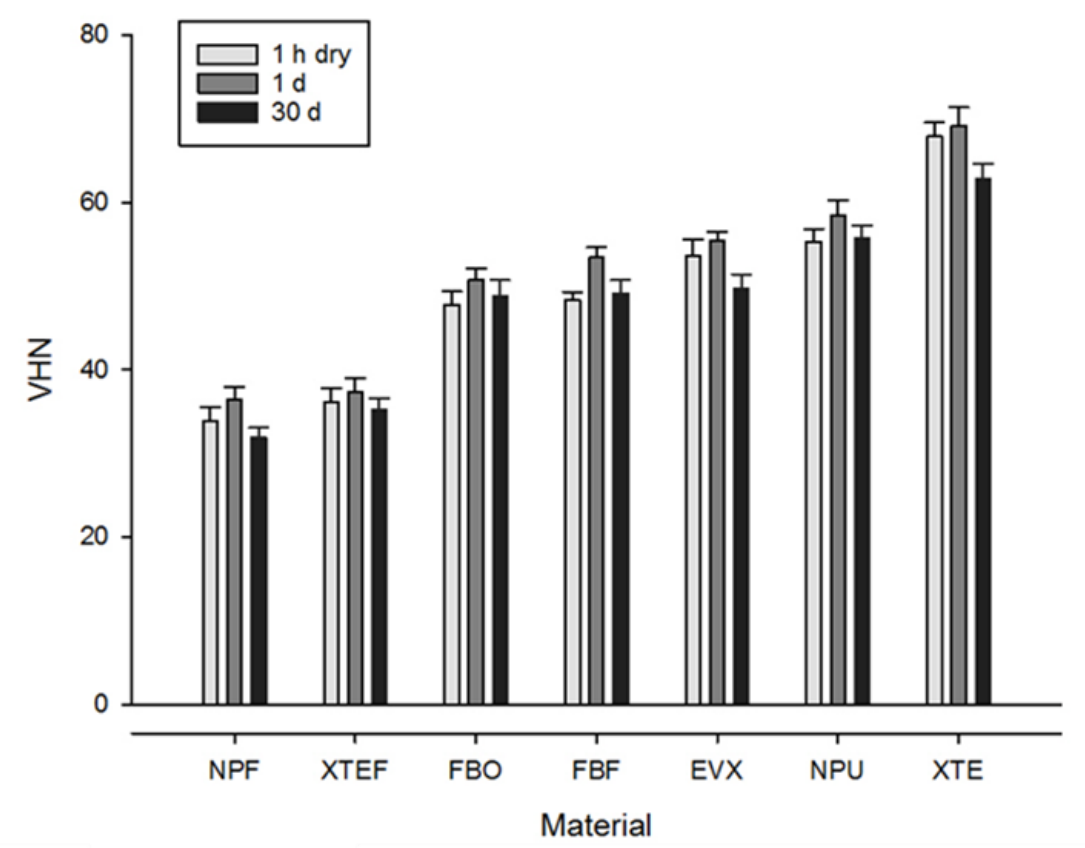

Figure 3: Vickers hardness (VHN) of resin-composites after 3 time intervals stored in water, $1 \mathrm{~h}$ dry, $1 \mathrm{~d}$ and $30 \mathrm{~d}$ at $37^{\circ} \mathrm{C}$ showing minimal reduction.

\section{B: $75 \%$ Ethanol $25 \%$ Water}

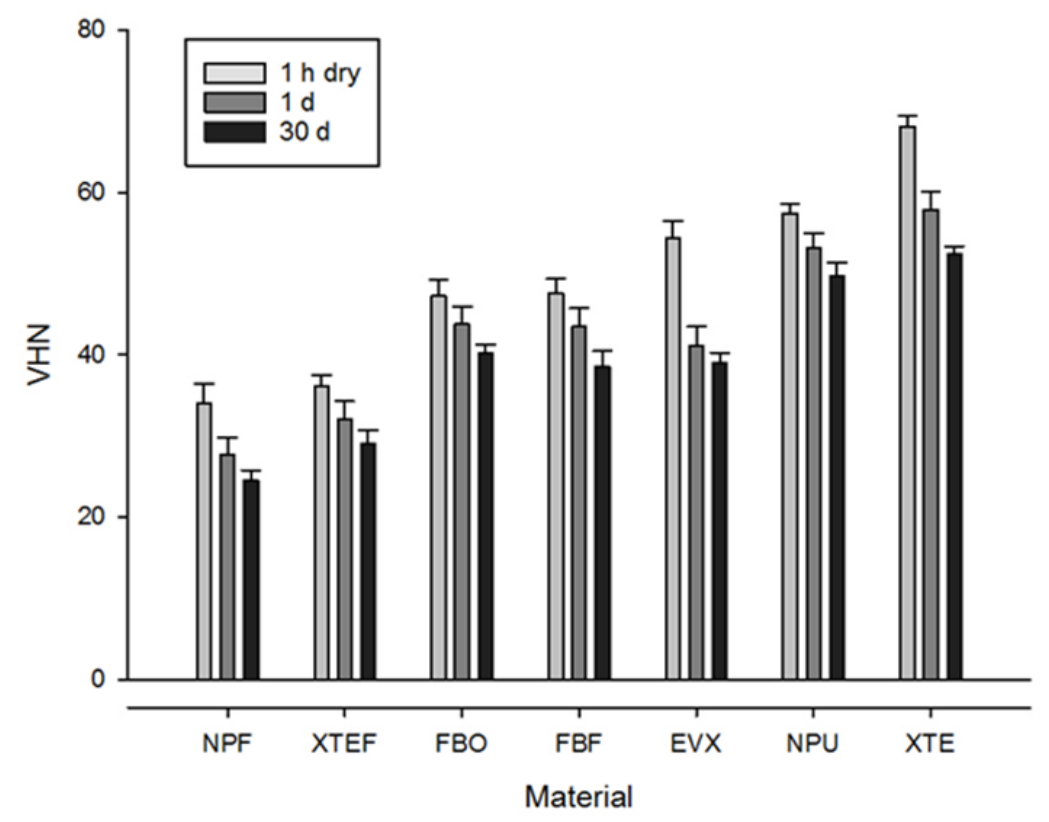

Figure 4 :Vickers hardness (VHN) of resin-composites after 3 time intervals stored in $75 \%$ Ethanol / water at $37^{\circ} \mathrm{C} ., 1 \mathrm{~h}$ dry, $1 \mathrm{~d}$ 
and $30 \mathrm{~d}$, showing significant reduction.

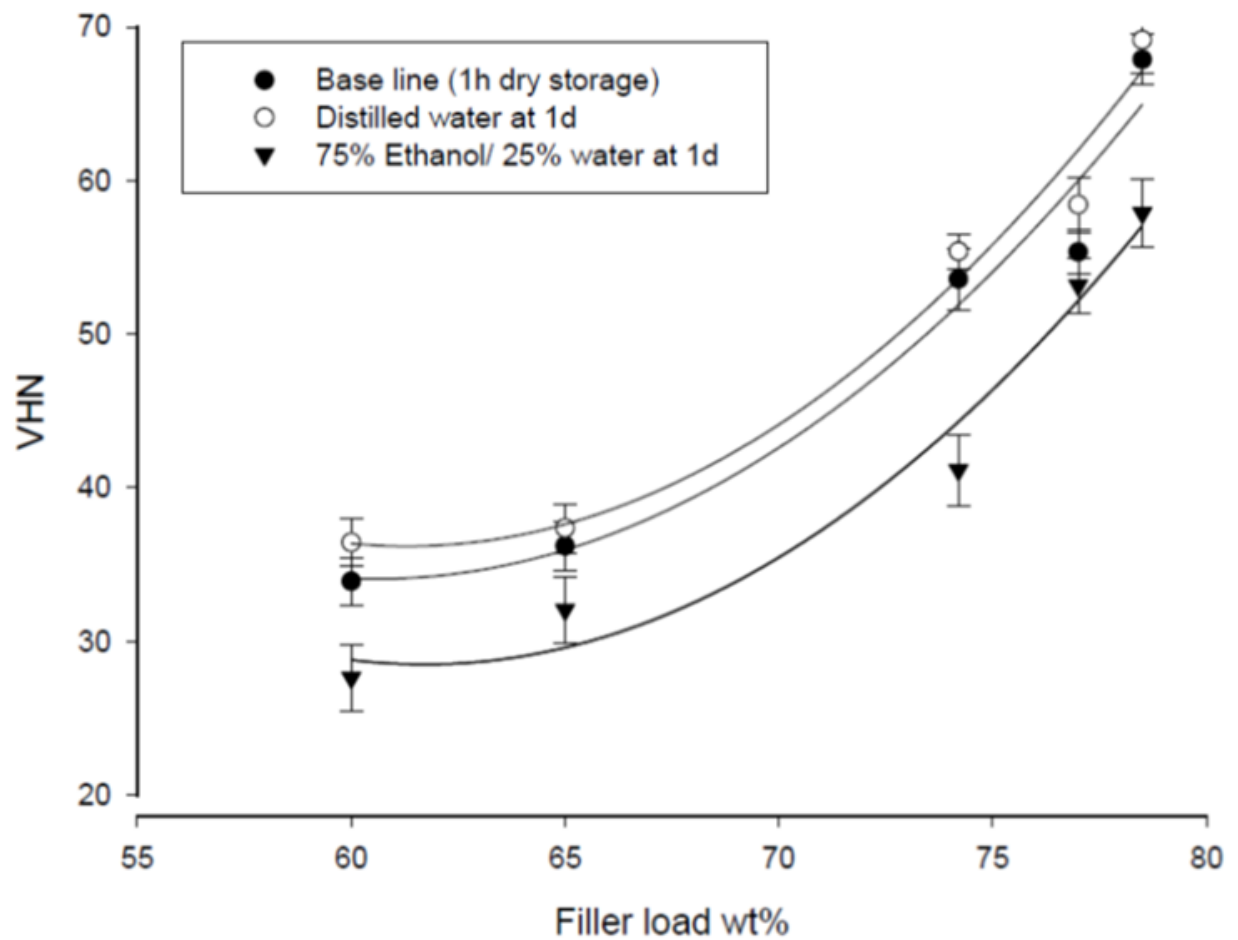

Figure 5: Quadratic regression analysis of micro-hardness (VHN) and filler loading wt \%. 


\subsection{Fracture toughness}

$\mathrm{K}_{\mathrm{IC}}$ values for the composites are presented in Table and shown graphically in Figure $6 . \mathrm{K}_{\mathrm{IC}}$ ranged from 0.96 to $2.14 \mathrm{M} . \mathrm{Pa} \mathrm{m}^{0.5}$ There were statistically significant differences between resin-composites $(p<0.05)$. EVX showed the highest $\mathrm{K}_{\mathrm{IC}}$, while NPF showed the lowest (after both 1 and $7 \mathrm{~d}$ storage). Although mean $\mathrm{K}_{\mathrm{IC}}$ increased numerically with storage time, except for EVX, there was no statistical significant change over time for the materials studied. However, there were statistically significant differences in $\mathrm{K}_{\mathrm{IC}}$ between the materials $(\mathrm{p}<0.05)$

Table 4: Fracture toughness (standard deviation) of resin-composites measured

\begin{tabular}{|c|c|c|}
\hline \multirow{2}{*}{ Materials } & \multicolumn{2}{|c|}{ Fracture toughness $\mathbf{K}_{\mathbf{I C}}\left(\mathbf{M . P a} \mathbf{m}^{\mathbf{0 . 5}}\right)$} \\
\cline { 2 - 3 } & $\mathbf{1 ~ D}$ & $\mathbf{7 ~ D}$ \\
\hline NPU & $1.23(0.14)^{\mathrm{a}}$ & $1.27(0.15)^{\mathrm{a}, \mathrm{d}}$ \\
\hline NPF & $0.96(0.09)^{\mathrm{c}}$ & $0.98(0.13)^{\mathrm{c}}$ \\
\hline EVX & $2.14(0.16)^{\mathrm{b}}$ & $2.10(0.18)^{\mathrm{b}}$ \\
\hline XTE & $1.37(0.23)^{\mathrm{a}}$ & $1.39(0.17)^{\mathrm{a}}$ \\
\hline XTEF & $0.97(0.08)^{\mathrm{c}}$ & $1.02(0.08)^{\mathrm{c}}$ \\
\hline FBF & $1.46(0.17)^{\mathrm{a}}$ & $1.58(0.30)^{\mathrm{a}, \mathrm{e}}$ \\
\hline FBO & $1.45(0.09)^{\mathrm{a}}$ & $1.47(0.12)^{\mathrm{a}}$ \\
\hline
\end{tabular}

The same superscript small letters indicate a homogeneous subset (columns) $(\mathrm{p}>0.05)$ 


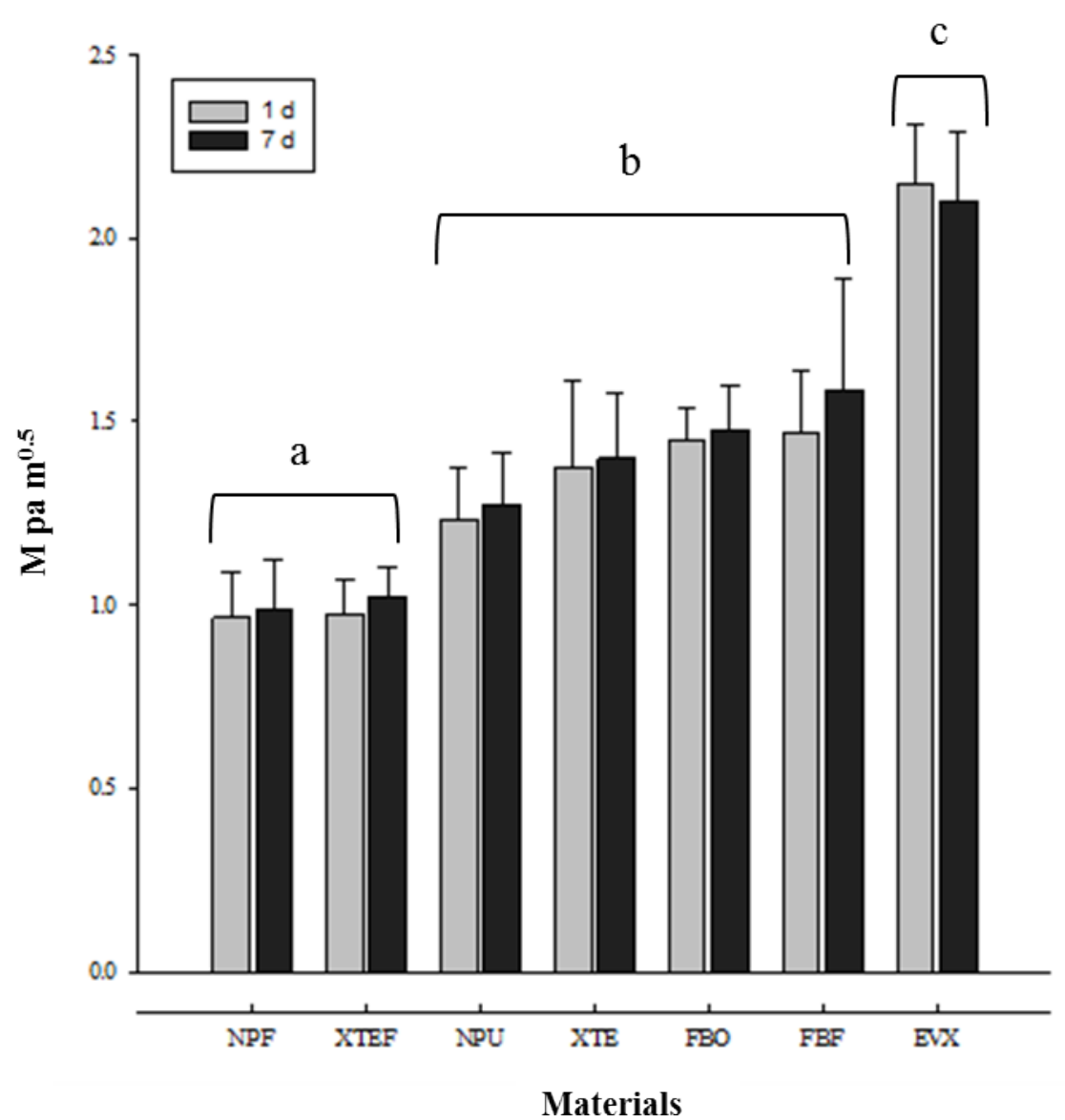

Figure 6: Fracture toughness (standard deviation) of composites after 1 and $7 \mathrm{~d}$ storage in water at $37^{\circ} \mathrm{C}$ The same superscript small letters indicate a homogeneous subset (columns) $(p>0.05)$

\subsection{SEM examination}

A representative SEM micrograph of EVX is presented at a magnification of $75 \mathrm{x}$ (Figure 7). Protruding fiber ends are apparent at the point of fracture of the single-edge-notched-beam specimen. In Figure 8, showing NPU at a magnification of $3000 \mathrm{X}$, an extracted hydroxyapatite fiber bundle is seen. These hydroxyapatite fibers had a mean length of $41 \mu \mathrm{m}$, within the range shown in Table 2. The combination of particulate fillers and fibers are visible in the SEMmicrographs of the NPU composite surface. 


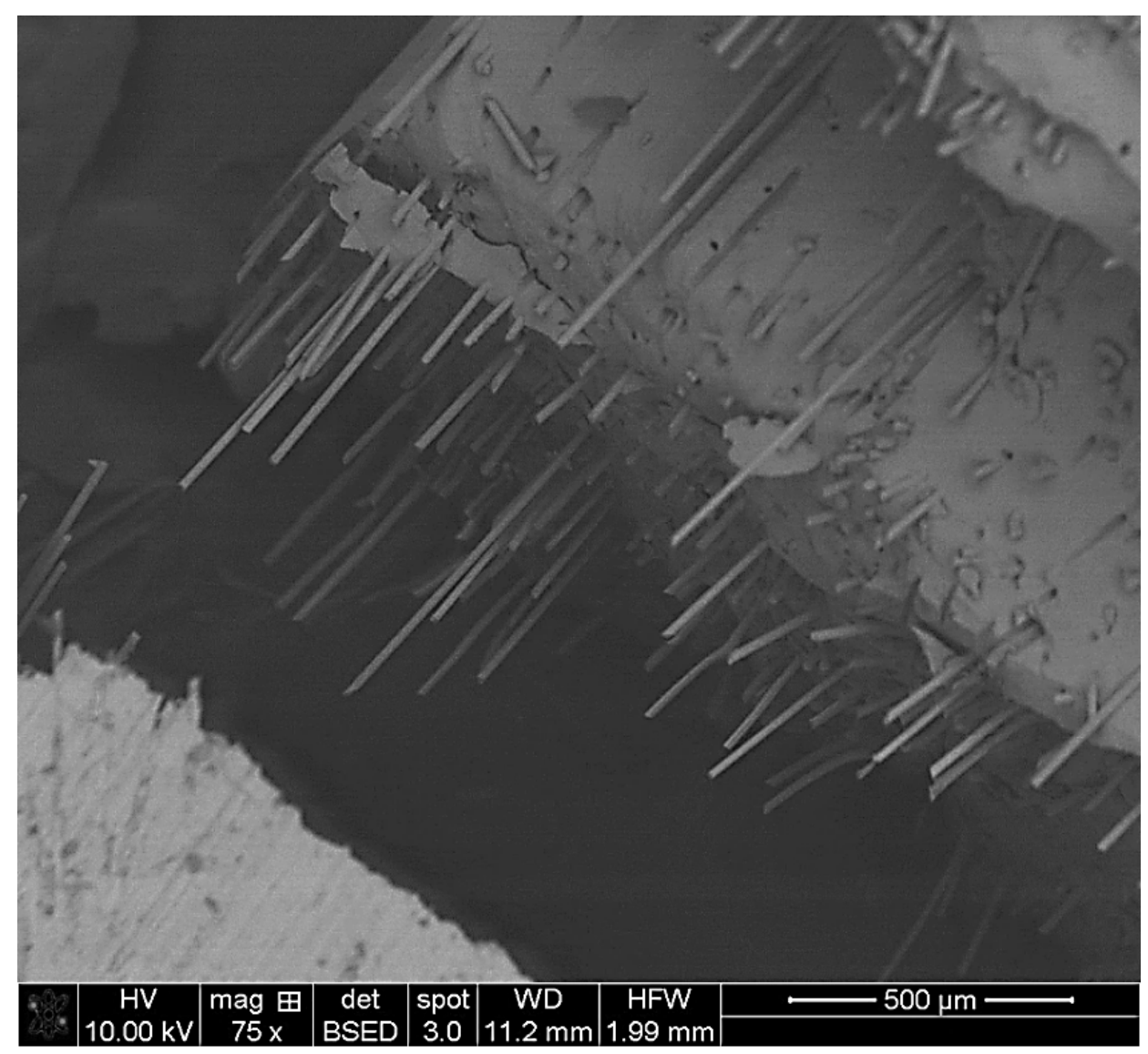

Figure 7: Image obtained in back scattered electron mode $(x 75)$ at a fracture site in the fiber reinforced resincomposite (everX ${ }^{\mathrm{TM}}$ ) with protruding E-glass fibers. 


\section{A}

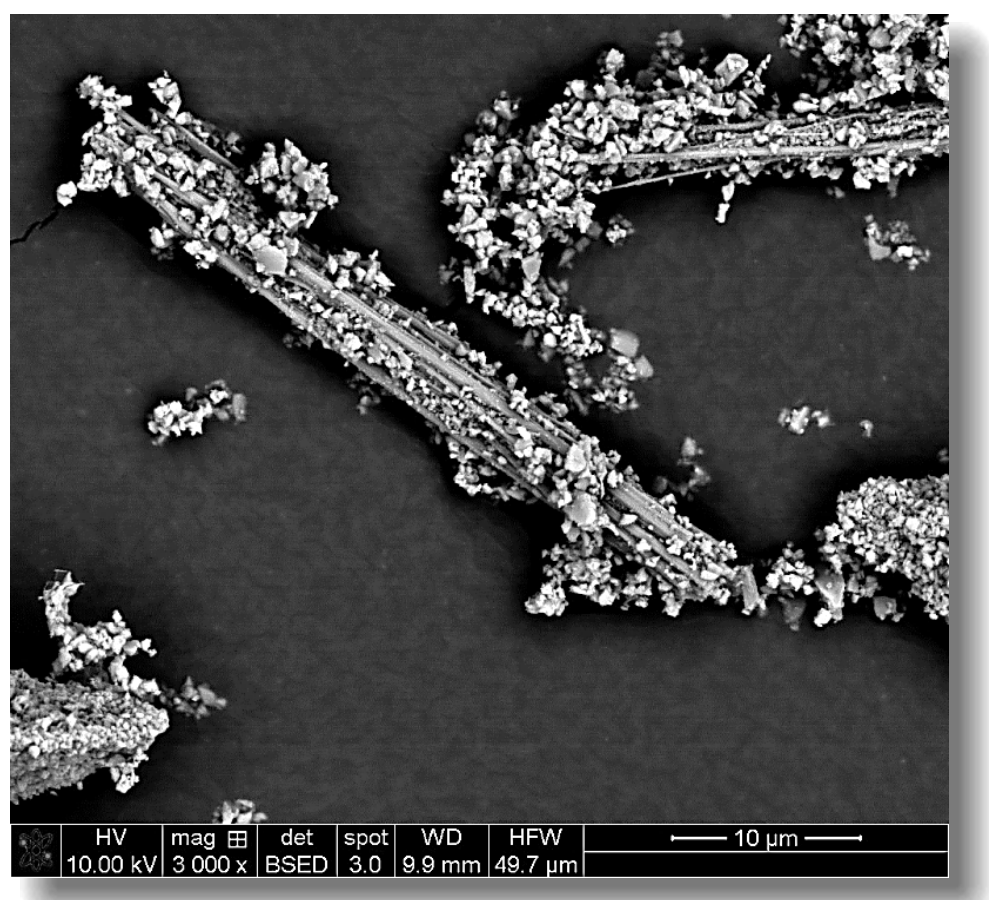

B

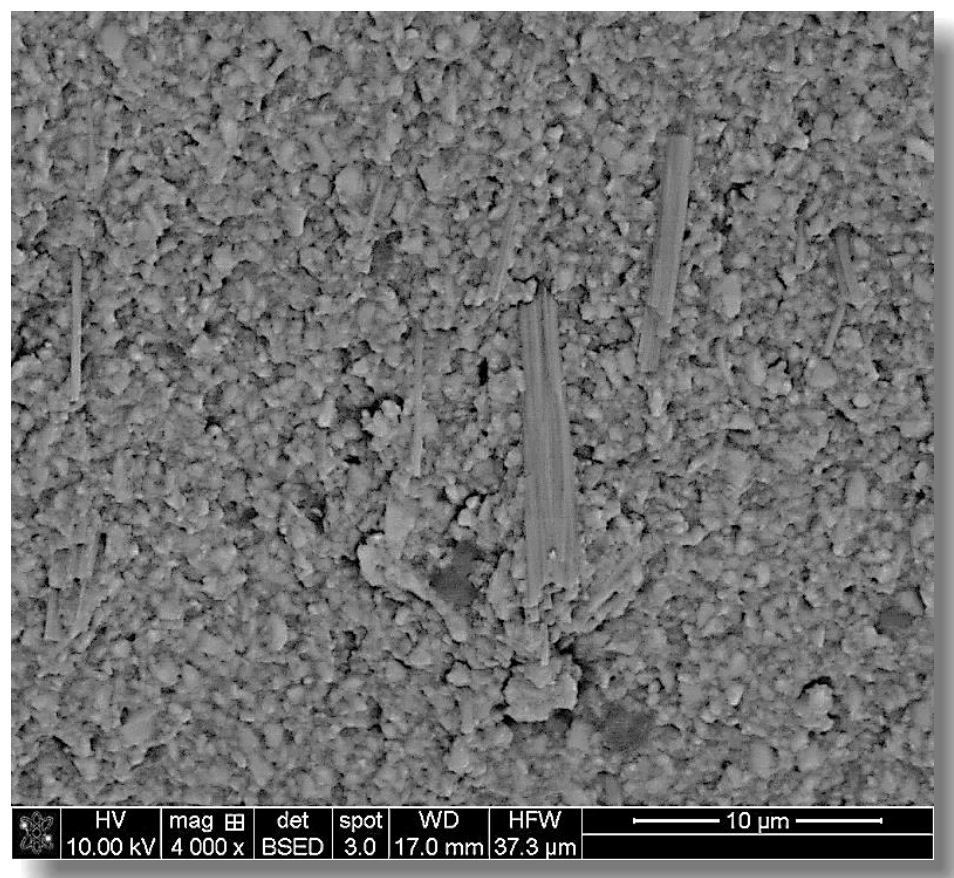

Figure 8 A: Image (x 3000) of extracted hydroxyapatite fiber bundles from fiber reinforced resin-composite (Novopro-fill ${ }^{\mathrm{TM}}$ ). B: Image obtained in back scattered electron mode $(\mathrm{x} 4000)$ at fracture site from fiber-reinforced resin-composite (Novopro-fill ${ }^{\mathrm{TM}}$ ). 


\section{Discussion}

\subsection{Micro-hardness}

The first part of this study reported the effect two different solvents (water, $75 \%$ ethanol/water), on Vickers hardness of resin composites. Significant effects on hardness were observed according to materials, storage medium, and time $(\mathrm{p}<0.05)$. Therefore, the first and second null hypotheses were rejected.

Several resin-composite factors can affect hardness including filler size, shape and fraction in the inorganic phase. Hardness generally increases with filler content $(23,24)$. This is physically understandable since, as the volume-fraction of filler increases, the point is reached where particles are mutually in contact within the matrix. Beyond this point stress is transferred across the material predominantly via (hard) particle-particle interactions. This results in non-linear dependence of modulus, hardness and related properties with filler content, as seen in Error! Reference source not found.. Hardness is also influenced by the specific composition and structure of the organic matrix (25). However, the physical and mechanical properties of a resin-composite can be weakened through chemical softening. The chemical composition of a resin-composite and the media to which it is exposed can therefore have a considerable effect on its properties (4).

This study reported the effect of food-simulating solvents on Vickers micro-hardness of resincomposites (distilled water, $75 \%$ ethanol/water). The top surface of the specimen was selected to measure the surface hardness. The irradiance generally reduces through the bulk of composite, owing to light being scattered by filler particles and resin matrix (26). Thus, the top surface provides an optimum measurement due to the photo-irradiation tip of the light cure unit focusing directly on the surface.

Water sorption usually increases with resin content and monomer hydrophilicity (27). The effect of diffusion-controlled water sorption first causes a softening of the matrix at the surface, with time needed for water to penetrate through the material bulk $(28,29)$. This effect is enhanced for certain monomers, but has also been shown to be enhanced in composites with less filler concentration (30). 
The surface hardness of all the restorative materials after $1 \mathrm{~d}$ of storage in distilled water increased relative to the baseline hardness. This is most probably due to additional monomer post-curing via cross-linking reactions in the resin phase over time. However, storage for $30 \mathrm{~d}$ in distilled water decreased surface hardness of the restorative materials. This will be due to water acting as a plasticizing molecule within the composite matrix, causing a softening of the polymer resin component by swelling the network and reducing the forces between polymeric chains (31). However, in 75\% ethanol/water storage, a significant reduction was seen in VHN between 1 and $24 \mathrm{~h}$ and continuing over 30 days. This finding is in agreement with previous studies that reported a significant reduction in hardness after $1 \mathrm{~d}$ storage in ethanol (15). The ethanol/water solution may degrade the resin and matrix/filler interface, as it easily diffuses and swells the resin matrix relieving tensile stress near the matrix/filler interface, which increases diffusion and leaching $(32,33)$. Decreases in surface hardness and wear resistance after storing resincomposites in ethanol have been ascribed to chemical softening influences (34).

EVX is a glass fiber reinforced resin-composite. VHN of EVX after $30 \mathrm{~d}$ reduced by $9 \%$ in water and by $29 \%$ in 70:30 ethanol: water. This VHN reduction is most probably due to hydrolytic disruption between the matrix and the glass fibers. Glass fiber reinforced composites absorb more water than conventional composites, which may also be related to the hydrophilicity of the polymer network $(4,35,36)$.

In this study, a positive correlation between VHN and filler loading was confirmed. This is in agreement with several studies concerned with filler loading $(24,37,38)$. NPF and XTEF materials had the lowest VHN - evidently due to their low filler loading. Some nano-hybrid resin based materials have shown good mechanical properties (39). The three nano-hybrid composites used in this experiment (XTE, FBF and FBO) showed a VHN reduction circa $20 \%$ after $30 \mathrm{~d}$ of ethanol/water storage. NPU is a hydroxyapatite fiber reinforced resin-composite, which had the least reduction (12\%) in VHN among all the investigated materials after storage in $75 \%$ ethanol/water. This might be due to the high filler load with a hydrophobic resin matrix compared to the other materials. The main resin constituents of NPU are Bis-EMA and UDMA, which have demonstrated better degradation resistance during chemical aging (40). 


\subsection{Fracture toughness}

For a long time, secondary caries has been reported as the most common reason for posterior resin-composite failure (3). However, other studies have demonstrated that the most common reason for replacement of posterior restoration after five years is bulk fracture of the composite filling (41). Restoration fracture has also been indicated as the main cause of failure in composite fillings used in larger cavities for periods of 11 years or longer $(42,43)$. A meta-analysis carried out on posterior resin-composite restorations found that a minimum of $5 \%$ of restorations will fail from material fracture within a ten-year observation period (44). The measurement of fracture toughness is, therefore, a worthwhile and often-used technique to characterize a material's resistance to fracture (45). $\mathrm{K}_{\mathrm{IC}}$ varied significantly within the total set of materials $(p<0.05)$. According to the method of application of these resin composite, they can be categorised into one of three bands: conventional composites (NPU and XTE), with $\mathrm{K}_{1 \mathrm{C}}$ being 1.23 and 1.37 M.Pa m ${ }^{0.5}$; bulk fill composites (EVX, FBO and FBF), with the highest value being 2.14 M.Pa m ${ }^{0.5}$ for EVX; and lastly, flowable composites (NPF and XTF), with $\mathrm{K}_{1 \mathrm{C}} 0.96$ and $0.97 \mathrm{M} . P a \mathrm{~m}^{0.5}$, respectively. Therefore, the third null hypothesis was rejected. However, there were no statistically significant differences in fracture toughness from 1 to 7 days water storage. Therefore, the fourth null hypothesis was accepted.

The Single-Edged-Notch (SEN) beam method $(46,47)$ was chosen to determine fracture toughness in the current research. Such specimens are particularly sensitive to the depth and width of the notch (46) which makes it difficult to make direct comparisons between studies.

Within this study, however, genuine differences in fracture behavior of resin-composites could be established as specimen preparation and measurement conditions were constant.

Storage in water, even in the short term, can lead to deterioration in mechanical properties regardless of material type. One possible exception to this was the Work of Fracture (16). Hydrolysis of bonds between filler and matrix is a potential mechanism for degradation by water (48-50). A toughening effect can also occur due to the aqueous plasticization of the resin matrix (16), that may enable the specimens to be more compliant before fracturing. However, swelling and deterioration of the cross-linked matrix within the composite, the leaching of components, and filler-matrix interface hydrolysis will ultimately result in a decline in mechanical properties $(16,51)$ 
While prior research has identified a positive association between $\mathrm{K}_{\mathrm{IC}}$ and filler load $(16,52,53)$, other studies of dental composites have seen an increase in the $\mathrm{K}_{\mathrm{IC}}$ with filler load up to $55 \mathrm{vol} \%$, followed by a decline of $\mathrm{K}_{\mathrm{IC}}$ with filler loads exceeding $55 \mathrm{vol} \%(23,54)$. The volume-fraction in the present study is not reported for some of the materials, and therefore the effect cannot be established. The shape, size, and distribution of filler particles are also relevant for mechanical properties (55).

In the present research, an improved resistance to crack propagation was seen in EVX, evidently due to this material's fiber and matrix-related properties. EVX contains fibers which are longer than the critical fiber length (56-58) which are more effective in transferring stress from the matrix. EVX has a semi-interpenetrated network (SIPN) matrix type, in which the existence of thermoplastic PMMA chains reduces the stiffness of the Bis-GMA monomer. These specific features may improve the flexural properties of the composite material and enhance its resistance to fracture development. These results are in agreement with extant literature on the topic (5759). The fiber length distribution of NPU fiber-reinforced composite was determined as between 8 and $103 \mu \mathrm{m}$, with two thirds of these fibers up to $50 \mathrm{um}$ and one third up to $100 \mathrm{um}$. This contrast with the length of the EVX fibers $(1,000-2,000 \mu \mathrm{m})$ may explain why EVX exhibited superior fracture toughness to NPU. This is consistent with a recent study of NPU showing that its mechanical properties were not significantly different from particulate filled composites (60). Furthermore, bundling of the hydroxyapatite nanofibers starts to occur when the hydroxyapatite nanofiber mass fraction reaches $10 \mathrm{wt} \%$ (61). At a hydroxyapatite nanofiber mass fraction of 20 $\mathrm{wt} \%$, the number of nanofiber bundles increased enough to create weak points in the dental resin matrix, resulting in decreased flexural strengths. Nanofiber bundling was also apparent in the SEM images of NPU (Figure 8A,B).

High $\mathrm{K}_{\mathrm{IC}}$ has been seen for both FBO and FBF, which are bulk-filled nano-composites. This could be due to reduced flaw-density, reduced flaw-size or an increase in monomer conversion (62). $\mathrm{K}_{\mathrm{IC}}$ can also be increased in nano-composites through enhanced bonding at the filler-matrix interface and through high strength filler and an increased surface area to volume ratio (63). Increasing the fracture resistance and strength of the matrix will also increase the resincomposite fracture toughness. 


\section{Conclusion}

Within the limitations of this study it was concluded that:

- A glass-fiber reinforced resin composite (EVX) showed the highest $\mathrm{K}_{\mathrm{IC}}$ while $\mathrm{NPF}$, XTEF (flowable composites) had the lowest $\mathrm{K}_{\mathrm{IC}}$.

- Reduction in surface hardness of EVX glass fiber reinforced composite in food simulating solvent ( $75 \%$ ethanol $25 \%$ water) supports the manufacturers' recommendations to cap this material with a conventional resin composite.

- The composite composition and the particular solvent environment both affect degradation of material properties.

\section{Acknowledgement}

GC Corporation, Tokyo, Japan for supplying everX Posterior 


\section{References:}

1. Fisher J, Varenne B, Narvaez D, Vickers C. The Minamata Convention and the phase down of dental amalgam. Bull World Health Organ. 2018;96(6):436-8.

2. Watts DC, el Mowafy OM, Grant AA. Fracture resistance of lower molars with Class 1 composite and amalgam restorations. Dent Mater. 1987;3(5):261-4.

3. Sarrett DC. Clinical challenges and the relevance of materials testing for posterior composite restorations. Dent Mater. 2005;21(1):9-20.

4. Al Sunbul H, Silikas N, Watts DC. Surface and bulk properties of dental resin-composites after solvent storage. Dent Mater. 2016;32(8):987-97.

5. Larsen IB, Freund M, Munksgaard EC. Change in Surface Hardness of Bisgma/Tegdma Polymer Due to Enzymatic Action. J Dent Res. 1992;71(11):1851-3.

6. Elliott J, Lovell L, Bowman C. Primary cyclization in the polymerization of bis-GMA and TEGDMA: a modeling approach to understanding the cure of dental resins. Dent Mater. 2001;17(3):221-9.

7. Martin N, Jedynakiewicz NM, Fisher AC. Hygroscopic expansion and solubility of composite restoratives. Dent Mater. 2003;19(2):77-86.

8. Feilzer A, De Gee A, Davidson C. Relaxation of polymerization contraction shear stress by hygroscopic expansion. J Dent Res. 1990;69(1):36-9.

9. Lohbauer U, Belli R, Ferracane JL. Factors involved in mechanical fatigue degradation of dental resin composites. J Dent Res. 2013;92(7):584-91.

10. Martos J, Osinaga PWR, Oliveira Ed, Castro LASd. Hydrolytic degradation of composite resins: effects on the microhardness. J Materials Research. 2003;6(4):599-604.

11. Lee S-Y, Huang H-M, Lin C, Shih Y-H. Leached components from dental composites in oral simulating fluids and the resultant composite strengths. J Oral Rehabil. 1998;25:575-88.

12. Shin MA, Drummond JL. Evaluation of chemical and mechanical properties of dental composites. J Biomed Mater Res A. 1999;48(4):540-5.

13. Sideridou ID, Karabela MM, Vouvoudi EC, Papanastasiou GE. Sorption and desorption parameters of water or ethanol in light-cured dental dimethacrylate resins. J Appl Polym Sci. 2008;107(1):463-75.

14. Calais J, Soderholm K-J. Influence of filler type and water exposure on flexural strength of experimental composite resins. J Dent Res. 1988;67(5):836-40.

15. McKinney J, Wu W. Chemical softening and wear of dental composites. J Dent Res. 1985;64(11):1326-31.

16. Ferracane J, Berge $\mathrm{H}$, Condon J. In vitro aging of dental composites in water-effect of degree of conversion, filler volume, and filler/matrix coupling. J Biomed Mater Res. 1998;42(3):46572.

17. Lin CT, Lee SY, Keh ES, Dong DR, Huang HM, Shih YH. Influence of silanization and filler fraction on aged dental composites. J Oral Rehabil. 2000;27(11):919-26.

18. Khan AS, Azam MT, Khan M, Mian SA, Ur Rehman I. An update on glass fiber dental restorative composites: a systematic review. Mater Sci Eng C Mater Biol Appl. 2015;47:26-39.

19. Garoushi S, Gargoum A, Vallittu PK, Lassila L. Short fiber-reinforced composite restorations: A review of the current literature. J Investig Clin Dent. 2018;9(3):e12330.

20. Schneider CA, Rasband WS, Eliceiri KW. NIH Image to ImageJ: 25 years of image analysis. Nat Methods. 2012;9(7):671.

21. Astm E. 399-90:" Standard test method for plane-strain fracture toughness of metallic materials. Annual book of ASTM standards. 1997;3(01):506-36.

22. Lloyd C, lannetta R. The fracture toughness of dental composites: I. The development of strength and fracture toughness. J Oral Rehabil. 1982;9(1):55-66.

23. Kim KH, Ong JL, Okuno O. The effect of filler loading and morphology on the mechanical properties of contemporary composites. J Prosthet Dent. 2002;87(6):642-9. 
24. McCabe J, Wassell R. Hardness of model dental composites-the effect of filler volume fraction and silanation. J Mater Sci Mater Med. 1999;10(5):291-4.

25. Marghalani HY. Resin-Based Dental Composite Materials. Handbook of Bioceramics and Biocomposites. 2016:357-405.

26. Price R, Derand T, Loney R, Andreou P. Effect of light source and specimen thickness on the surface hardness of resin composite. Am J Dent. 2002;15(1):47-53.

27. Sideridou ID, Karabela MM. Sorption of water, ethanol or ethanol/water solutions by lightcured dental dimethacrylate resins. Dent Mater. 2011;27(10):1003-10.

28. De Moraes RR, Marimon JLM, Jochims Schneider LF, Sinhoreti MAC, Correr-Sobrinho L, Bueno M. Effects of 6 months of aging in water on hardness and surface roughness of two microhybrid dental composites. J Prosthodont. 2008;17(4):323-6.

29. Finer $Y$, Santerre J. Salivary esterase activity and its association with the biodegradation of dental composites. J Dent Res. 2004;83(1):22-6.

30. Finer $Y$, Santerre J. Influence of silanated filler content on the biodegradation of bisGMA/TEGDMA dental composite resins. J Biomed Mater Res A. 2007;81(1):75-84.

31. Drummond JL. Degradation, fatigue, and failure of resin dental composite materials. J Dent Res. 2008;87(8):710-9.

32. Aguiar FH, Braceiro AT, Ambrosano GM, Lovadino JR. Hardness and diametral tensile strength of a hybrid composite resin polymerized with different modes and immersed in ethanol or distilled water media. Dent Mater. 2005;21(12):1098-103.

33. Ferracane J, Marker VJJodr. Solvent degradation and reduced fracture toughness in aged composites. 1992;71(1):13-9.

34. Pilliar R, Vowles R, Williams D. The effect of environmental aging on the fracture toughness of dental composites. J Dent Res. 1987;66(3):722-6.

35. Vallittu PK. Effect of 180-week water storage on the flexural properties of E-glass and silica fiber acrylic resin composite. Int J Prosthodont. 2000;13(4):334-9.

36. Abdel-Magid B, Ziaee S, Gass K, Schneider M. The combined effects of load, moisture and temperature on the properties of E-glass/epoxy composites. Compos Struct. 2005;71(3):320-6.

37. Rueggeberg FA, Ergle JW, Mettenburg DJ. Polymerization Depths of Contemporary Light-Curing Units Using Microhardness. J Esthet Restor Dent. 2000;12(6):340-9.

38. Wang R, Habib E, Zhu X. Evaluation of the filler packing structures in dental resin composites: From theory to practice. Dent Mater. 2018;34(7):1014-23.

39. De Souza GM. Nanoparticles in Restorative Materials. Nanotechnology in Endodontics: Springer,cham 2015. p. 139-71.

40. Moraes RR, Sinhoreti MA, Correr-Sobrinho L, Ogliari FA, Piva E, Petzhold CL. Preparation and evaluation of dental resin luting agents with increasing content of bisphenol-A ethoxylated dimethacrylate. J Biomater Appl. 2010;24(5):453-73.

41. Brunthaler A, König F, Lucas T, Sperr W, Schedle A. Longevity of direct resin composite restorations in posterior teeth: a review. Clinical oral investigations. 2003;7(2):63-70.

42. Van Nieuwenhuysen J-P, D'hoore W, Carvalho J, Qvist V. Long-term evaluation of extensive restorations in permanent teeth. J Dent. 2003;31(6):395-405.

43. Van Dijken J. Direct resin composite inlays/onlays: an 11 year follow-up. J Dent. 2000;28(5):299-306.

44. Heintze SD, Rousson V. Clinical effectiveness of direct class II restorations-a meta-analysis. J Adhes Dent. 2012;14(5):407-31.

45. Ilie N, Hilton T, Heintze S, Hickel R, Watts D, Silikas N, et al. Academy of Dental Materials guidance-Resin composites: Part I-Mechanical properties. Dent Mater. 2017;33:880-94

46. Schneider SJ. Engineered Materials Handbook, Volume 4: Ceramics and Glasses: ASM International; 1991. 
47. Belli R, Wendler M, Zorzin JI, Lohbauer U. Practical and theoretical considerations on the fracture toughness testing of dental restorative materials. Dent Mater. 2018;34(1):97-119.

48. Curtis A, Shortall A, Marquis P, Palin W. Water uptake and strength characteristics of a nanofilled resin-based composite. J Dent. 2008;36(3):186-93.

49. Vallittu PK, Ruyter I, Ekstrand K. Effect of water storage on the flexural properties of E-glass and silica fiber acrylic resin composite. Int J Prosthodont. 1998;11(4):340-50.

50. Miettinen VM, Narva KK, Vallittu PK. Water sorption, solubility and effect of post-curing of glass fibre reinforced polymers. Biomaterials. 1999;20(13):1187-94.

51. Alrahlah A, Silikas N, Watts D. Hygroscopic expansion kinetics of dental resin-composites. Dent Mater. 2014;30(2):143-8.

52. Watanabe H, Khera SC, Vargas MA, Qian F. Fracture toughness comparison of six resin composites. Dent Mater. 2008;24(3):418-25.

53. Zhao D, Botsis J, Drummond JL. Fracture studies of selected dental restorative composites. Dent Mater. 1997;13(3):198-207.

54. Kim K-H, Park J-H, Imai Y, Kishi T. Fracture toughness and acoustic emission behavior of dental composite resins. Eng Fract Mech. 1991;40(4-5):811-9.

55. Johnson W, Dhuru V, Brantley W. Composite microfiller content and its effect on fracture toughness and diametral tensile strength. Dent Mater. 1993;9(2):95-8.

56. Abouelleil H, Pradelle N, Villat C, Attik N, Colon P, Grosgogeat B. Comparison of mechanical properties of a new fiber reinforced composite and bulk filling composites. Restor Dent Endod. 2015;40(4):262-70.

57. Garoushi S, Mangoush E, Vallittu M, Lassila L. Short fiber reinforced composite: a new alternative for direct onlay restorations. Open Dent J. 2013;7:181-5.

58. Lassila L, Garoushi S, Vallittu PK, Säilynoja E. Mechanical properties of fiber reinforced restorative composite with two distinguished fiber length distribution. J Mech Behav Biomed Mater. 2016;60:331-8.

59. Leprince JG, Palin WM, Vanacker J, Sabbagh J, Devaux J, Leloup G. Physico-mechanical characteristics of commercially available bulk-fill composites. J Dent. 2014;42(8):993-1000.

60. Yancey EM, Lien W, Nuttall CS, Brewster JA, Roberts HW, Vandewalle KS. Properties of a New Nanofiber Restorative Composite. Oper Dent. 2019;44(1):34-41.

61. Vidotti HA, Manso AP, Leung V, do Valle AL, Ko F, Carvalho RM. Flexural properties of experimental nanofiber reinforced composite are affected by resin composition and nanofiber/resin ratio. Dent Mater. 2015;31(9):1132-41.

62. Kovarik R, Ergle J. Fracture toughness of posterior composite resins fabricated by incremental layering. J Prosthet Dent. 1993;69(6):557-60.

63. Chan K, Lee Y-D, Nicolella D, Furman B, Wellinghoff S, Rawls R. Improving fracture toughness of dental nanocomposites by interface engineering and micromechanics. Eng Fract Mech.

2007;74(12):1857-71. 